\title{
PERAN ORANG TUA DALAM PEMBENTUKAN KEPRIBADIAN ANAK DI DESA KANCILAN
}

\author{
Khotimah Khoirul Mufida, Moh Kanzunnudin, Erik Aditia Ismaya \\ Universitas Muria Kudus, Jl, Lkr, Utara, Kayuapu Kulon, Gondangmanis, Kec. Bae, Kabupaten Kudus, \\ Jawa Tengah 59327 \\ Correspondence Email: mufidakhotimahkhoirul@gmail.com
}

\begin{abstract}
The research aims to analyze the role of parents in the formation of children's personalities in Kacilan Village and to analyze the obstacles faceb by parents in shaping children's personality in Kancilan Village. This research is a qualitative research with descriptive methods. This research uses data collection techniques in the from of literature study, observation, interviews, recording, recording, and shooting. The results showed that the role of parents in shaping children's personality, namely parents in modeling, parents in teaching religion, parents teaching manners, and parents in instilling honesty. As for the obstacles faced by parents in teaching children's personalities, namely low parental education, parent's busy work, factors from the children themselves, environmental factors, and social media factors. Based on data analysis, it can be concluded that the role of parents in shaping children's personality is quite good. This can be seen from observations and interview that the role of parents in Kancilan Village has been carried out well.
\end{abstract}

Keywords:

The Role of Parentst; Child's Personality

\begin{abstract}
Abstrak
Penelitian ini bertujuan untuk menganalisis peran orang tua dalam pembentukan kepribadian anak Di Desa Kancilan dan menganalisis kendala yang dihadapi orang tua dalam pembentukan kepribadian di Desa Kancilan. Penelitian ini merupakan penelitian kualitatif dengan metode deskriptif. Penelitian ini menggunakan teknik pengumpulan data berupa studi pustaka, observasi, wawawncara, perekaman, pencatatan, dan pemotretan. Hasil penelitian menunjukkaan bahwa peran yang dilakukan orang tua dalam pembentukan kepribadian anak yakni orang tua dalam memberi keteladanan, orang tua dalam mengajarkan agama, orang tua dalam mengajarkan sopan santun, dan orang tua dalam menanamkan kejujuran. Adapun kendala yang dihadapi orang tua dalam pembentukan kepribadian anak yakni rendahnya pendidikan orang tua, kesibukan orang tua dalam bekerja, faktor dari anak itu sendiri, faktor lingkungan, dan media sosial. Berdasarkan analisis data, dapat disimpulkan bahwa peran orang tua dalam pembentukan kepribadian anak dapat dikatakan sudah cukup baik. hal tersebut dapat dilihat dari wawancara dan observasi bahwa peran orang tua yang ada di desa kancilan sudah telaksana dengan baik.
\end{abstract}

Kata Kunci:

Peran Orang Tua; Kepribadian Anak.

\section{A. PENDAHULUAN}

Orang tua merupakan figur yang baik untuk anak, guru pertama bagi anak, menjadi panutan dan ceminan bagi kepribadian anak. sikap kepribadian anak tegantung pada rang tuanya, karena orang tua yang mengajarkan pertama kali kepada anaknya tentang sesuatu yang baik dan buruk dari segi sikapmaupun perilaku yang dilakukan sebagaimana yang dikemukan Hendri (2019) bahwa orang tua merupakan orang yang mempunyai tanggung dan memberikan bimbingan kepada anaknya dalam membentuk kepribadian nak dengan penuh 
tanggung jawab dalam suasana kasih sayang.

Segala masalah yang dihadapi rang tua di zaman sekarang ini memaksakan situasi ataupun peran orang tua dalam membentuk kepribadian anaknya menjadi berubah. Tidak semua rang tua mempunyai pla asuh aatau cara yang sma dalam mendidik anaknya agar menjadi pribadi yang baik. peran inilah yang akan mempengaruhi prses interaksi antara rang tua dengan anaknya. Dengan begitu dapat disimpulkan bahwa peran rang tua sangat besar tehadap pembentukan kepribadian anak.

Kepribadian anak dapat dilihat dari bagaimana peran rang tua dalam mengajarkan, menanamkan nilai-nilai sosial, dan nilai-nilai agama baik dari keluarga pedagang, guru, wiraswasta, petani, dan berbagai pekerjaan lainnya. Kepribadian anak tidak hanya dibentuk melalui didikan rang tua saja melainkan dipengaruhi oleh berbagai hal yaitu perkembangan teknolgi, lingkungan, dan teman sekitarnya. Sebagaimana yang dikemukan Djaali (2015: 1) bahwa kepribadian sangat perlu diketahui dan dipelajari karena kepribadian berkaitan dengan pola yang dianut leh masyarakat di lingkungan akan mengalami penerimaan yang baik. tetapi sebaliknya jika kepribadian tidak sesuai apalagi bertentangan dengan pla yang dianut dilingkungannya, maka akan tejadi penolakan dari masyarakat.

Berdasarkan permasalahan yang ada di Desa Kancilan bahwa masih ada anak yang kepribadiannya kurang baik dikarenakan kesibukan rang tua yang menjadikan anak kurang mendapatkan perhatian dan didikan, kurangnya wawasan dan pengetahuan yang dimiliki orang tua. Sehingga orang tua tidak bisa mengntrol, serta mengawasi aktivitas anak sepenuhnya. Hal tersebut dapat dilihat bahwa pada zaman sekarang ini masih ada anak yang berperilaku tidak baik, suka berbohong, tidak sopan baik dari segi ucapan maupun tingkah laku.

Adapun beberapa penelitian yang memperkuat penelitian ini yakni penelitian yag sebagaimana dijelaskan oleh Isman (2019). Berdasarkan penelitian tesebut menunjukkan bahwa upaya rang tua dalam membentuk kepribadian anak di Desa Banti Kecamatan Baraka Kabupaten Enrekang adalah menanamkan nilainilai agama sejak dini, melakukan pengawasan dan memberikan keteladanan. Kendala yang dihadapai rang tua dalam membentuk kepribadaian anak di Desa Banti kecamatan Baraka Kabupaten Enrekang adalah pengaruh lingkungan (teman sebaya), kuragnya waktu tehadap anak, dan pengaruh media sosial. Penelitian kedua oleh Safitri (2019). Berdasarkan penelitian menunjukkan bahwa: 1) Peran orang tua dalam pembentukan kepribadian anak di era milenial di Desa Talang Tinggi Kecamatan Seluma Barat Kabupaten Seluma belum sepenuhnya dapat dilakukan oleh orang tua, hal ini dikarenakan terbatasnya waktu dan kesibukan orang tua dalam kehidupan sehari-hari serta kurangnya wawasan dan pengalaman yang dimiliki orang tua, sehingga mereka kurang mampu mengontrol, mengawasi, serta mengendalikan segala kegiatan serta aktivitas anak dikehidupan sehari-hari. 2) beberapa faktor yang menjadi penghambat orang tua dalam pembentukan kepribadian anak di era milenial yaitu kesibukan orang tua dalam bekerja sehari-hari, masuknya berbagai budaya berupa pengaruh dunia yang sering disebut dengan milenial. Sebagai contoh yang 
ditemukan oleh peneliti yaitu adanya teknologi seperti televisi, intenet, handphone yang memiliki kontenkonten yang berbau pornografi atau game online.

\section{B. METODE PENELITIAN}

Penelitian ini dilaksanakan di Desa Kancilan Kecamatan kembang Kabupaten Jepara. Penelitian yang digunakan pada penelitian ini adalah penelitian kualitatif deskriptif. Sugiyono (2017: 15) mengatakan bahwa metode penelitian kualitatif adalah meted penelitian yang berlandasakan pada filsafat pstpsitivisme yang digunakan untuk meneliti kndisi bjek yang alamiah, dimana peneliti sebagai instrument kunci dan hasilnya lebih menekankan makna daripada generalisasi. Ali (dalam isman, 2019) berpendapat bahwa penelitian deskriptif merupakan suatu penelitian yang berupaya memberikan gambaran mengenai fenomena dan keadaan yang terjadi dilokasi penelitian berdasarkan pada kondisi alamiah itu (natural setting) dari objek penelitian, karena berdasarkan ada kondisi alamiah itu maka berbagai fenmena yang nampak tersebut kemudian diekspoitasi dan perdalam dan mengacu pada pelaku, waktu, tempat, dan kejadian yang ada secara konstektual melalui pengumpulan data yang diperoleh. Informan utama pada penelitian ini adalah orang tua yang memiliki anak usia sekolah dasar dan anak usia dasar di Desa Kancilan.

\section{HASIL DAN PEMBAHASAN}

(1) Peran Orang Tua dalam Pembentukan Kepribadian Anak di Desa Kancilan Kecamatan Kembang

Peran orang tua dalam pembentukan kepribadia anak sagat penting, karena baik baik buruknya anak tergantung bagaimana orang tua dalam mendidik anaknya. Jika orang tua mampu memberi arahan dan contoh yang baik kepada anaknya, maka anak akan melihat apa yag dilakukan orang tuanya. Sehingga kepibadian anak terbentuk bagaimana orang tua dalam mencontohkannya. Dengan begitu peran orang tua sangat dibutuhkan dalam pembetuka kepibadia anak.

1. Orang tua dalam Memberi Keteladanan

Sebagai orang tua harus bisa memberikan contoh yang baik kepada anaknya, karena pada dasaya anak memerlukan sosok teladan dan panutan yang mampu mengarahkannya. Sehigga apapun yang dilakukan orang tuanya kemudian dilihat anak maupun yang dialami anak dari orang tuaya baik secara langsung maupun tidak langsung akan terekam dalam memori anak yang terus diingat bahkan sangat memungkinkan ditiru oleh anak, karena peran orang tua dalam memberi keteladanan sangat besar pengaruhya pada anak. Hikmatullah dan Fachmi (2020) mengatakan bahwa keteladanan ialah mendidik anak dengan cara memberikan contoh yang baik agar dijadikan panutan yang baik juga dalam berkata, bersikap dan dalam semua hal yag mengadung kebaikan.

Cara orang tua dalam memberikan keteladanan kepada anak di Desa Kancilan yakni mencontohkan dan membiasakan anak dengan cara 
mengajarkan anak berbuat baik seperti halnya bersikap sopan santun kepada semua orang khususnya orang tua dan orang yang lebih tua. Orang tua juga membiasakan anak untuk disiplin waktu, agar sejak kecil anak belajar untuk bertanggung jawab. Anak dibiasakan orang tuanya untuk saling tolong menolong kepada teman saudara maupun orang yang membutuhkan, orang tua membiasakan anak dalam hal mendirikan sholat dan mengaji orang, agar sejak kecil ia anak berdampingan dengan hal yang berhubungan dengan agama.

Banyak

sekali

keteladanan yang diberikan orang tua kepada anaknya, walaupun dalam memberikan keteladanan setiap orang tua berbeda namun tidak jauh berbeda antara orang tua satu dengan orang tua lainnya dengan tujuan agar anak terbiasa sejak kecil untuk melakukan apa yang dicontohkan maupun yang diajarkan orang tuanya. Dengan adanya keteladanan dalam pendidikan keluarga merupakan metode yang sangat berpengaruh dan tebukti paling berhasil dalam mempersiapkan dan membentuk aspek moral, akhlak, spirit, karakter dan etos sosial anak. Hikmatullah dan Fachmi (2020).

2. Orang Tua dalam Mengajarkan Agama

Pertama kali yang diajarkan orang tua kepada anaknya adalah agama. Jika anak memiliki pondasi mengenai agama, amaka anak memiliki bekal untuk kehidupanyya yang akan datang. Sebagaimana yang dikemukakan Imelda (dalam Masrofah Dkk, 2020) bahwa pendidikan agama merupakan bagian yang sangat penting yang berkenaan dengan aspek-aspek sikap, akhlak, keagamaan dan sosial masyarakat. Agama memberi motivasi hidup dalam kehidupan.

Orang tua dalam mengajarkan agama kepada anak di Desa Kancilan yakni tidak hanya memberikan motivasi dan menyuruh anak untuk melakukan hal yang berhubungan dengan agama saja. Tetapi orang tua juga membiasakan anaknya untuk ikut serta dalam kegiatan keagamaan dan memberikan contoh telebih dahulu agar anak dapat meniru apa yang dilakukan orang tuanya yakni dalam hal mendirikan sholat, mengaji, berpuasa saat bulan ramadhan. Selain itu orang tua juga menjadi penasehat terbaik bagi anaknya ketika anak bersikap maupun berperilaku tidak sesuai syariat agama.

Peran orang tua dalam mengajarkan agama kepada anak sangat penting. Karena dengan memberikan pendidikan agama pada anak, sikap maupun perilaku anak akan mudah dibentuk. Karena agama merupakan hal utama dalam pembentukan kepribadian anak. Dewantara (2015) dalam konteks pendidikan agama, aktivitas belajar dengan demikian berisi rangkaian aktivitas untuk mengubah dan menentukan 
hidup manusia dalam kaitan dengan diri, sesama, dan tuhannya. Pendidikan agama pada akhirnya menjadi sebuah tindakan yang hendak memanusiakan dan hendak sekaligus mengillahikan manusia.

3. Orang Tua dalam Mengajarkan Sopan Santun

Sebagai orang tua harus bias mengajarkan sopan santun, karena dengan mengajarkan sopan santun kelak anak dapat berkomunikasi dan berinteraksi dengan baik dimanapun ia berada. Dalam menerapkan sopan santun memang tidak mudah, tetapi jika orang tua mampu mengjarkan sopan santun hingga berhasil. Maka anak akan tumbuh menjadi pribadi yang bisa menghormati dan menghargai orang lain. Ramadani (2020) berpendapat bahwa sopan santun merupakan perilaku seseorang yang menjunjung tinggi nilai-nilai menghormati, menghargai, tidak sombong dan berakhlak mulia dengan cara menghormati dan berakhlak mulia dengan cara menghormati orang yang lebih tua, menyapa jika bertamu dengan orang lain, berbicara dengan berbahasa yang santun, serta beperilaku yang baik. Dengan kata lain sopan santun adalah peratiuan yang timbul dari hasil pergaulan sekelompok individu atau masyarakat yang membentuk suatu sistem etika atau moral.

Orang tua dalam mengajarkan sopan santun kepada anak di Desa Kancilan tidak hanya menyuruh anak untuk bersikap sopan santun tetapi orang tua juga memberikan motivasi dan contoh yang baik dalam kegiatan sehari-harinya yakni anak dibiaskan untuk menghormati orang tua terlebih orang yang lebih tua, berbahasa karma halus, dan tak lupa orang tua juga mengapresiasi ketika anak bersikap sopan santun.

Mengajarkan sopan santun sejak kecil dengan tujuan agar anak terbiasa bersikap dan berperilaku sopan santun tanpa disuruhpun ia melakukannya. Iwan (2020) mengatakan bahwa sopan santun adalah suatu sikap atau tingkah laku yang ramah tehadap orang lain, sopan santun juga didapat dipandang oelh masyarakat lain. Memang tidak mudah untuk menerapkan sopan santun pada diri kita sendiri, tetapi jika orang tua kita berhasil mengajarkan sopan santun sejak kecil anak kita akan tumbuh menjadi seseorang yang bisa menghormati dan menghargai orang lain.

4. Orang Tua Dalam Menanamkan Kejujuran

mungkin

Sebagai orang tua sebisa kejujuran kepada anak. Karena kejujuran merupakan hal yang paling penting dan harus diajarkan kepada anak sejak kecil. Sebab dengan menanamkan kejujuran sejak kecil, anak akan lebih mudah untuk menyerap sehingga tertanam sampai anak tersebut dewasapun akan memiliki kebiasaan yang baik. Hermanto 
(2019) bependapat bahwa karakter jujur merupakan kebenaran dalam sesuai dengan keinginan hati nuraninya yang dilandasi dengan keteguhan iman serta tidak menipu dan berbohong pada orang lain baik secara lisan maupun tindakan.

\section{Orang tua dalam} menanamkan kejujuran kepada anak di Desa Kancilan tidak hanya memberikan arahan, nasehat dan mencontohkan kejujuran dalam sehari-harinya saja. Namun orang tua menjai teman bagi anaknya, ketiak anak berbohong orang tua tidak hanya marah-marah memaksakan anaknya untuk jujur tetapi lebih memilih cara yang halus agar anak tersebut mau berkata jujur. Tetapi ada juga orang tua yang diam saja ketika anak berbohong agar anak tersebut dengan sendirinya berkata jujur. Dengan menanmkan kejujuran diharapkan agar ketika dewasa anak menjadi pribadi yang jujur karena sejak kecil ia sudah diajarkan dan dibiasakan untuk jujur.

Peran orang tua dalam menanamkan kejujuran pada anak sangat penting, karena kejujuran merupakan hal yang sangat diperlukan dalam berbagai aspek. Chairilsyah (2016) jujur adalah sikap atau sifat seseorang yang menyatakan sesuatu dengan sesungguhnya dan apa adanya, tidak ditambahi ataupun dikurangi. Kejujuran menjadi penting karena dengan mengakui apa yang kita pikirkan, rasakan, dan lakukan sebagaimana adanya, seseorang dapat terhindar dari rasa bersalah yang timbul akibat bohong.

2) Kendala yang dihadapi Orang Tua dalam Pembentukan Kepribadian Anak di Desa Kancilan

Pada dasarnya anak-anak yang masih berusia 6-12 tahun, tingkat rasa keinginan tahu mereka sangat besar, oleh karena itu mereka lebih cepat dalam hal meniru apa yang mereka lihat maupun mereka dengar. Apalagi di zaman yang modern seperti ini banyak informasi yang mudah didapat dari televisi maupun intenet, sehingga anak dengan mudahnya mendapatkan informasi tersebut. Disini peran orang tua dalam hal mengawasi anak sangatlah penting dan diperlukan. Karena dizaman sekarang ini, jika anak tidak diawasi maka anak tidak akan menjadi seperti yang diinginkan orang tua pada umumnya. Jadi orang tua sebisa mungkin memaksimalkan perannya. Namun dalam menjalankan perannya, orang tua tidak beitu mudah, apalagi peran orang tua dalam pembentukan kepribadian anak.

Kendala yang dihadapi orang tua dalam pembentukan kepribadian anak di Desa Kancilan yakni rendahnya pendidikan menjadi kendala mendasar dalam pembentukan kepribadian anak. Kemudian kesibukan orang tua dalam bekerja, sehingga orang tua 
belum bisa mengatur waktu dengan baik dalam mengurus, mendidik maupun mengawasi anaknya. Selain itu faktor anak itu sendiri dan faktor lingkungan juga menjadi kendala karena anak beitu cepat dalam hal meniru, apalagi setiap harinya anak bermain dengan temannya dan yang terakhir yaitu media social yang tentunya banyak pengaruh buruknya daripada pengaruh baiknya.

Rendahnya pendidikan berpengaruh dalam pembentukan kepribadian anak. Orang tua kurang maksimal dalam pembentukan kepribadian anak karena keterbatasannya pengetahuan yang dimiliki orang tua. Kemudian kesibukan orang tua dalam bekerja, Li Dkk (dalam Rofingah dan mahpur, 2018) kesibukan bekerja menjadikan perhatian orang tua kepada anak berkurang sehingga waktu orang tua semakin sedikit untuk mendidik anaknya yang akhirnya komunikasi antara orang lain dengan anak juga berkurang. Selain itu karena faktor anak itu sendiri, Sa'diyah (2017) faktor internal merupakan semua pengaruh yang bersumber dari dalam diri anak tersebut, seperti keadaan keturunan dan konstitusi tubuhnys sejak dilahirkan dengan segala perlengkapan yang melekat padanya. Faktor lingkungan juga menjadi kendala dalam pembentukan kepribadian anak, isman (2019) lingkungan sangat mempengaruhi perkembangan kepribadian anak, ketika temannya memiliki kepribadian anak akan melakukannya seperti yang dilakukan oleh temannya. Betapa pentingnya peran orang tua dalam memperlihatkan lingkungan pergaulan anak. Dan yang terakhir yaitu media sosial, Isman (2019) media sosial sangat berpengaruh terhadap kepribadian anak terhadap anak-anak. Betapa pentingnya orang tua memperhatikan anaknya.

\section{SIMPULAN}

Berdasarkan hasil penelitian dan pembahasan dapat disimpulkan bahwa peran orang tua dalam pembentukan kepribadian anak di Desa Kancilan Kecamatan Kembang Kabupaten Jepara yakni orang tua dalam memberi keteladanan, oramg tua dalam mengajarkan agama, orang tua dalam mengajarkan sopan santun, dan orang tua dalam menanamkan kejujuran

Kendala yang dihadapi orang tua dalam pemebentukan kepribadian anak di desa kancilan Kecamatan kembang kabupaten jepara yakni rendahnya pendidikan, selain itu juga karena kesibukan orang tua dalam bekerja, faktor dari anak itu sendiri, faktor lingkungan, dan media sosial.

\section{E. DAFTAR PUSTAKA}

Dewantara, Agustinus Wisnu. 2015. "Pancasila Sebagai Pondasi Pendidikan Agama di Indonesia". Jurnal Ilmiah Civis., 5 (1), 640-653. 
Djaali. 2015. Psikologi Pendidikan. Jakarta: PT Bumi Aksara.

Hendri. 2019. "Peran Pola Asuh Orang Tua Terhadap pembentukan Konsep Diri Anak". Jurnal atTaujaih: Bimbingan dan Konseling Islam., 2 (2), 56-71.

Hermanto, Joko Dwi. 2019. Pengembangan Buku Pengayaan Menulis Teks Fabel Bermuatan Nilai Karakter Jujur dan Tanggung Jawab Bagi Peserta Didik Kelas VII SMP. Skripsi. Universitas Negeri Semarang.

Hikmah dan Teguh, Fahmi. 2020. "Keteladanan Orang Tua dalam Islam”. Jurnal Pendidikan Agama Islam., 7 (2), 165-187.

Isman, Muh. Suyono. 2019. Peran Orang Tua dalam Pembentukan Kepribadian Anak di Desa Binti Kecamatan Baraka Kabupaten Enrekang. Skripsi. Uin Alaudin Makasar.

Iwan. 2020. "Merawat Sikap Sopan Santun dalam Lingkungan Pendidikan". Jurnal Agama Islam., 4 (1), 98-121.

Masrofah, Tria et.al. 2020. "Peran Orang Tua dalam Membina Akhlak Remaja (Studi di Kelurahan Air Duku, Rejang Lebong-Bengkulu)”. Jurnal Pendidikan Agama Islam., 2 (2), 39-58.

Ramadani, Restu. 2020. Pelaksanaan Bimbingan Kelompok dalam Mengembangkan Perilaku Sopan Santun Siswa di Sekolah Menengah Pertama Negei 33 Pekanbaru. Skripsi. UIN Suska Riau.
Rofingah, Nangimatur dan Mahpur Mohammad. 2018. "Efektivitas Komunikasi Berkualitas untuk Meningkatkan Kehangatan dalam Pengasuhan pada Orang Tua Sibuk Bekerja di Kb-Tk IT AlHikmah”. Psikoislamika: Jurnal Psikologi dan Psikologi Islam., 15 (2). 12-20.

Sa'diyah, Rika. 2017. "Pentingnya Melatih kemandirian Anak". Jurnal Komunikasi Antar Perguruan Agama Islam., 16 (1), 3146.

Safitri, Enelia. 2019. Peran Orang Tua dalam Pembentukan Kepribadian Anak di Desa Talang Tinggi Kecamatan Seluma Barat Kabupaten Seluma. Skripsi. Institut Agama Islam Negeri (IAIN) Bengkulu.

Sugiyono. 2017. Metode Penelitian Pendidikan (Pendekatan kuantitatif, kualitatif, dan R\&D). Bandung: Alfabeta. 